\title{
Pelatihan Penggunaan Media Daring sebagai Alternatif Pembelajaran Era Pandemi
}

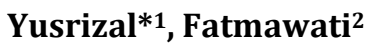 \\ 1,2Sekolah Tinggi Keguruan dan Ilmu Pendidikan Amal Bakti, Indonesia \\ *e-mail: yusrizaldns@gmail.com ${ }^{1}$,fatmecincau@gmail.com ${ }^{2}$
}

\begin{abstract}
Abstrak
Tujuan utama pelaksanaan kegiatan ini yaitu untuk memberikan pelatihan kepada guru dalam menggunakan media daring sebagai alternatif pembelajaran di era pandemi covid-19. Kegiatan ini dilaksanakan dengan metode daring dan metode luring. Metode daring digunakan dengan memanfaatkan aplikasi zoom meeting. Sedangkan metode luring digunakan untuk kegiatan evaluasi. Kegiatan ini dilaksanakan selama tiga kali pertemuan dengan materi yaitu pelatihan menggunakan google form, pelatihan menggunakan aplikasi zoom dan google meet serta pelatihan menggunakan video pembelajaran. Adapun peserta kegiatan ini terdiri dari guru sekolah dasar yang ada di bawah yayasan PAB Sumatera Utara. Berdasarkan analisis hasil kegiatan maka dapat disimpulkan bahwa setelah kegiatan dilaksanakan terjadinya peningkatan pemahaman guru dalam menggunakan dan mengaplikasikan media daring dalam pembelajaran. Peningkatan tersebut terlihat dari meningkatnya: 1) kemampuan menggunakan google form sebagai media untuk absen hadir serta membuat soal berbasis online; 2) kemampuan menggunakan zoom dan google meet sebagai fasilitas pembelajaran; dan 3) kemampuan membuat video pembelajaran menggunakan filmora dan kinemaster.
\end{abstract}

Kata kunci: media pembelajaran daring, pembelajaran era pandemi

\begin{abstract}
The main purpose of implementing this activity is to provide training to teachers in using online media as an alternative to learning in the era of the covid-19 pandemic. This activity is carried out using online and offline methods. The online method is used by utilizing the Zoom Meeting application. While the offline method is used for evaluation activities. This activity was carried out for three meetings with the material, namely training using google forms, training using the zoom and google meet applications and training using learning videos. The participants of this activity consisted of elementary school teachers under the North Sumatra PAB foundation. Based on the analysis of the results of the activity, it can be concluded that after the activity was carried out there was an increase in teacher understanding in using and applying online media in learning. This increase can be seen from the increase in: 1) the ability to use google forms as a medium for absent attendance and making online-based questions; 2) the ability to use zoom and google meet as learning facilities; and 3) the ability to make learning videos using Filmora and Kinemaster.
\end{abstract}

Keywords: learning of the pandemic era, online media

\section{PENDAHULUAN}

Coronavirus Disease 2019 atau yang lebih dikenal dengan sebutan Covid-19 merupakan jenis virus baru yang dilaporkan pertama kali muncul di Wuhan Tiongkok pada bulan Desember tahun 2019 [1], [2] . Sejak tanggal 30 Januari 2020 wabah Covid-19 ditetapkan oleh WHO dengan status pandemi [3]. Sejak saat itu seluruh tatanan kehidupan berubah secara drastis, perubahan besar juga dirasakan pada sektor pendidikan dengan ditutupnya hampir seluruh sekolah di Indonesia [2], [4]. Beberapa kebijakan dibuat oleh pemerintah untuk hentikan penebaran virus ini, seperti harus pemakaian masker, mengaplikasikan physical distancing atau jaga jarak untuk menghindar adu fisik, serta melaksanakan pembatasan sosial) di beberapa daerah yang penyebarannya cukup kronis [2]. Pada bidang pendidikan, untuk menahan penyebaran Covid-19, banyak negara, termasuk pemerintahan Indonesia, keluarkan peraturan supaya semua kegiatan pembelajaran di sekolah diberhentikan dan diganti dengan peraturan belajar dari rumah dengan mekanisme pembelajaran jarak jauh semenjak 24 Maret 2020

Work From Home (WFH) selama era pandemi menjadi satu-satunya alternatif yang dapat dilakukan guru dalam mengganti aktivitas belajar. Work From Home (WFH) atau yang 
dikenali dengan PJJ yaitu pembelajaran yang dilakukan secara daring yang sebelumnya aktivitas belajar mengajarkan dilaksanakan di sekolah atau secara konservatif [5]. Pembelajaran online sebagai satu pembelajaran yang memakai internet dengan aksesbilitas, sambungan, elastisitas, dan kekuatan untuk menyuguhkan berbagai tipe korelasi dalam pembelajaran [5]. Prawiyogi menjelaskan jika Pembelajaran Jarak Jauh (PJJ) ialah pembelajaran dengan memakai satu media yang berpeluang terjadi hubungan di antara pendidik dan pembelajar [6]. Dalam pembelajaran jarak jauh di antara pendidik dan pembelajar tidak bertatap muka langsung, dalam kata lain lewat pembelajaran jarak jauh bisa saja di antara pendidik dan pembelajar berlainan tempat, bahkan juga dapat dipisah oleh jarak yang paling jauh.

Dalam prakteknya banyak dijumpai faktor-faktor yang harusnya diperhatikan oleh setiap guru supaya pelaksanaan PJJ bisa berjalan dengan tepat diantaranya yaitu perhatian, kepercayaan diri guru, pengalaman guru, penggunaan teknologi, kreatif menggunakan media, dan menjalin interaksi dengan siswa [6]. Kemendikbud telah bekerjasama dengan berbagai pihak dalam mengembangkan sistem pembelajaran di era pandemi. Kerjasama tersebut yaitu dengan Microsoft, Quipper, Ruang Guru, Google Indonesia, Kelas Pintar, Sekolahmu, dan Zenius [7].

Pembelajaran jarak jauh merupakan suatu metode pembelajaran yang terus dikembangkan oleh guru dan pendidik [8]. Beragam ide dilaksanakan untuk pastikan aktivitas belajar masih tetap berjalan walau tidak ada sesi tatap muka langsung. Tehnologi, seperti internet, smartphone, dan netbook saat ini dipakai secara luas untuk memberikan dukungan pembelajaran jarak jauh [9].

Salah satunya masalah yang ditemui dengan peralihan proses pembelajaran itu ialah ongkos proses pembelajaran yang semakin karena diperlukan ongkos untuk tehnologi yang dipakai pada proses pembelajaran daring. Salah satunya contoh yang membutuhkan ongkos tambahan ialah pengadaan pulsa untuk paket internet. Paket internet ini benar-benar diperlukan pada proses pengadaan dan pengaksesan materi pembelajaran secara daring. Untuk menangani masalah ongkos tambahan ini, pemerintahan Indonesia lewat Kementerian Pengajaran dan Kebudayaan sudah keluarkan peraturan yaitu rileksasi dana Kontribusi Operasional Sekolah (BOS) yang bisa dipakai oleh unit pengajaran untuk pengadaan pulsa paket internet untuk pelajar dan guru. Disamping itu, pemerintahan akan memberinya bantuan paket internet untuk pelajar dan guru terhitung dari bulan September sampai Desember 2020.

Salah satunya masalah alih bentuk proses pembelajaran ialah ongkos proses pembelajaran yang makin bertambah karena tehnologi yang dipakai pada proses pembelajaran online memerlukan ongkos. Contoh keperluan ongkos tambahan ialah pemberian pulsa untuk paket internet. Paket internet ini benar-benar diperlukan pada proses pengadaan dan pengaksesan materi pembelajaran secara online. Untuk menangani limitasi ongkos tambahan ini, pemerintahan Indonesia lewat Kementerian Pengajaran dan Kebudayaan keluarkan peraturan kelonggaran dana kontribusi operasional sekolah (BOS) yang bisa dipakai unit pengajaran untuk menyiapkan pulsa paket internet untuk pelajar dan guru. Disamping itu, pemerintahan akan memberinya bantuan paket internet untuk pelajar dan guru mulai September 2020 s/d Desember 2020 [1]

Kendala lain yang muncul dalam pembelajaran akibat pandemi yaitu keterbatasan penguasaan keterampilan teknologi informasi baik oleh para guru maupun siswa. Guru di hampir seluruh bagian Indonesia tidak semuanya mampu menggunakan teknologi dan faktor ini menyebabkan mereka membatasi diri dalam memilih dan menggunakan aplikasi teknologi dalam menunjang pembelajaran jarak jauh. Akibatnya, banyak diantara guru yang hanya menyajikan materi dan tugas masih bersifat seadanya dan dikerjakan secara mandiri oleh siswa bersama orang tuanya dirumah. Tentunya hal ini akan menyebabkan pembelajaran menjadi tidak maksimal sehingga siswa terkesan hanya di beri beban dengan berbagai tugas yang di berikan oleh guru yang tidak mampu menggunakan teknologi sebagai media dalam pembelajaran jarak jauh. Karena proses pembelajaran jarak jauh tidak sekedar hanya membagi materi pembelajaran, tetapi harus ada proses aktivitas belajar mengajarkan secara daring. Selainnya hubungan dengan materi pembelajaran, diperlukan ada hubungan di antara 
pembelajar dengan pendidik dan hubungan di antara sama-sama pembelajar (antara murid) yang lain [1].

Berdasarkan hasil pengamatan yang telah dilaksanakan pada sejumlah sekolah SD swasta PAB sumatera utara maka dapat disimpulkan bahwa pola pembelajaran yang dilakukan oleh guru selama pandemi belum menemukan format yang jelas. Banyak guru yang belum siap dengan kondisi pembelajaran yang berubah drastis. Hal ini sebabkan oleh kurangnya kemampuan guru dalam menguasai teknologi sehingga pembelajaran secara daring sangat sulit dijalankan. Oleh karena itu pelatihan tentang pembelajaran daring sangat dibutuhkan oleh para guru sekolah dasar swasta PAB Sumatera Utara.

\section{METODE}

Kegiatan ini dilaksanakan di sekolah dasar PAB Sumatera Utara yang terdiri dari 31 sekolah. Kegiatan ini dilaksanakan tiga hari pada bulan Februari 2021. Adapun bentuk pelaksanaan kegiatan ini dijabarkan di bawah ini:

1. Tahapan Persiapan: Tahap ini tim pelaksana mengidentifikasi permasalahan terkait dengan implementasi media pembelajaran berbasis daring yang di gunakan di sekolah dasar PAB Sumatera Utara. Selanjutnya permasalahan tersebut dipetakan sehingga pelaksanaan pelatihan dapat sesuai dengan yang diharapkan. Pada tahap ini tim pelaksana mengkoordinasikan dengan seluruh kepala sekolah tentang prosedur pelaksanaan pelatihan.

2. Tahap Pelaksanaan: pelatihan penggunaan media daring dilakukan dengan metode daring menggunakan aplikasi zoom meeting, namun kegiatan ini tetap mempertahankan konsep pendekatan andragogi, pemahaman tentang praktik dan materi tetap menjadi prioritas utama dalam kegiatan ini. Kegiatan ini diikuti oleh seluruh guru sekolah dasar PAB Sumatera Utara. Materi pelatihan diantaranya yaitu 1) pelatihan penggunaan google form; 2) pelatihan penggunaan zoom dan google meet 3) pelatihan pembuatan video pembelajaran.

3. Tahap Evaluasi: evaluasi dilakukan secara langsung pada saat sesi akhir pertemuan. Evaluasi dilakukan untuk melihat tingkat capaian guru dalam mengimplementasikan hasil materi pelatihan secara konkrit. Setelah selesai pelatihan tim pelaksana tetap menjalin komunikasi baik dengan peserta pelatihan maupun dengan kepala sekolah melalui berbagai di media sosial seperti grup whatsapp maupun facebook

\section{HASIL DAN PEMBAHASAN}

Pelatihan pengguaan media berbasis daring diawali dengan penjelasan terkait tentang hakikat media pembelajaran daring. Sebelum masuk ketahap pelatihan tim pelaksana berupaya memberikan pemahaman kepada peserta pelatihan bahwa banyaknya media online pada saat ini bisa digunakan dan dimanfaatkan sebagai sarana penunjang aktivitas pembelajaran. Namun poin terpenting dalam pembukaan ini adalah tim menegaskan bahwa semua media tersebut sangat mudah digunakan. Hal ini dimaksudkan agar para peserta yang notabennya adalah guru dengan kemampuan IT yang rendah merasa lebih percaya diri dalam menerima materi pelatihan.

Pelatihan ini dilakukan dengan 3 kali pertemuan, setiap pertemuan dilakukan selama 4 jam. Pertemuan pertama merupakan shering session antara pembicara dengan peserta tentang kebijakan pemerintah yang mengubah pola pembelajaran menjadi pembelajaran jarak jauh. Kemudian pada pertemuan ini diberikan kesempatan kepada 5 orang guru untuk menyampaikan kendala-kendala yang dialami selama melaksanakan pembelajaran jarak jauh. Dari beberapa pendapat yang dikemukakan oleh peserta dapat disimpulkan bahwa masih banyak guru yang belum menguasai teknologi sebagai alat dalam membantu proses pembelajaran. Guru cenderung lebih memilih memberikan tugas kepada siswa untuk dikerjakan 
di rumah bersama orang tua, dan siklusnya demikian terus menerus. Hal ini tentu menjadikan siswa tertekan sehingga jika terus dibiarkan maka akan menyebabkan kurangnya motivasi siswa dalam belajar. Pertemuan ini dilanjutkan dengan diskusi tentang media pembelajaran yang dapat dipakai dalam pembelajaran jarak jauh.

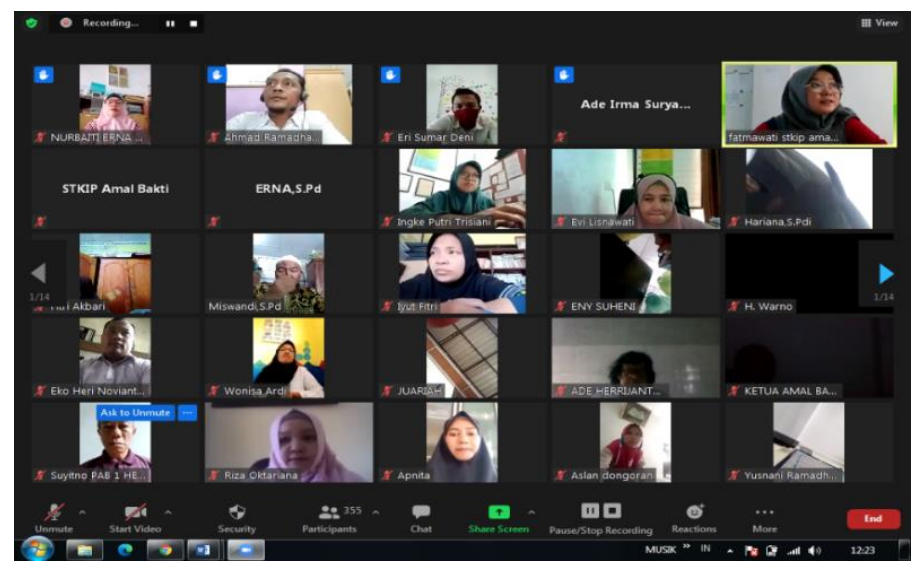

Gambar 1. Dokumentasi Pertemuan Pertama Pelatihan

Dalam pertemuan pertama dipaparkan secara ringkas materi tentang kegunaan google form serta tahapan-tahapan dalam pembuatan google form melalui andriod dan PC, pada sesi ini juga dipaparkan dengan cara mengimplementasikan google form. Pelatihan yang dilaksanakan diantaranya pembuatan akun Google, cara membuat form daftar hadir siswa serta membuat soal latihan untuk siswa dan membuat link yang selanjutnya dibagi di kelas, dan cara menilai tugas siswa. Sesi ini juga memberikan pelatihan mengenai pembuatan form presensi yang dapat diisi langsung oleh siswa.

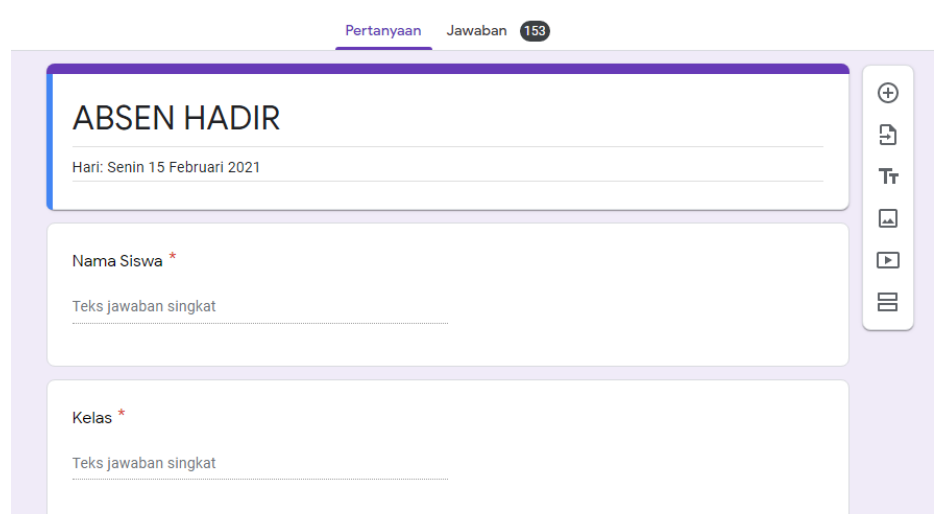

Gambar 2. Pembuatan Absen Hadir Menggunakan Google Form

Pertemuan kedua pada kegiatan ini menyajikan materi tentang penggunaan aplikasi zoom dan google meet. Sesi ini dijelaskan tentang bagaimana cara menggunakan aplikasi zoom dan google meet mulai dari pembuatan akun dan tahapan penggunaannya. Dalam pertemuan ini juga disajikan pelatihan tentang pembuatan video pembelajaran. Pembuatan video pembelajaran menggunakan aplikasi Filmora dan Kinemaster. Materi disalurkan dengan metode penjelasan dan langsung dipandu oleh pembicara yang membuat peserta dapat memahami dengan baik terkait materi yang disampaikan. Selanjutnya pelatihan ini ditutup pada pertemuan terakhir dengan memberikan evaluasi yang tujuannya untuk melihat capaian para peserta terkait pemahaman terhadap materi yang telah disampaikan. Evaluasi dilaksanakan dengan metode tatap muka dimana seluruh peserta secara berkelompok diminta untuk membuat beberapa tugas tentang materi yang telah diberikan lalu mempresentasikan ke depan dalam bentuk peer teaching sementara kelompok lainnya menanggapi kekurangan hasil presentasi dari kelompok yang tampil. Setelah secara keseluruhan kelompok tampil maka dilakukan 
penilaian yang mana hasil tersebut menjadi bahan rujukan untuk pengambilan keputusan dalam pelaksanaan kegiatan ini.

Berdasarkan hasil pelatihan yang telah dilakukan selama tiga kali pertemuan, maka dapat dijelaskan bahwa guru mulai memahami cara menggunakan google form, zoom meeting, google meet, hingga membuat video pembelajaran. Namun masih diperlukan pendampingan sehingga guru dapat menjadi lebih mahir menggunakan teknologi dalam pembelajaran selama pandemi.

\section{KESIMPULAN}

Kegiatan PKM pelatihan penggunaan media pembelajaran berbasis daring ini telah mampu meningkatkan pemahaman peserta yang mayoritasnya adalah guru SD dalam mengaplikasikan dan mengintegrasikan media pembelajaran berbasis daring dalam pembelajaran sehari-hari. Hal tersebut terlihat dari hasil evaluasi pada pertemuan terakhir yang dapat disimpulkan bahwa media-media yang dibuat oleh para peserta sudah layak diberikan kepada siswa. Selain itu berdasarkan penilaian juga dapat dikatakan bahwa pemahaman para peserta yang mengikuti pelatihan terhadap penggunaan teknologi sebagai media pembelajaran telah meningkat.

\section{UCAPAN TERIMA KASIH}

Penulis mengucapkan terima kasih kepada STKIP Amal Bakti yang telah memberikan dukungan secara financial terhadap pelaksanaan kegiatan ini. Diharapkan hasil kegiatan dapat bermanfaat untuk bagi para pembaca khususnya bagi guru di lingkungan PAB demi perbaikan pembelajaran di masa yang akan datang.

\section{DAFTAR PUSTAKA}

[1] R. Dwiyansaputra, I. G. P. S. Wijaya, F. Bimantoro, G. S. Nugraha, and A. Aranta, "Pelatihan Penggunaan Aplikasi Zoom Untuk Proses Pembelajaran Daring Pada Masa Pandemi Covid19 Di SD Negeri 10 Cakranegara," J. Begawe Teknol. Inf., vol. 2, no. 1, pp. 62-69, 2021

[2] Y. Yusrizal, B. S. Lubis, F. Fatmawati, and D. Muzdalifah, "Pengaruh Metode Visit Home dan Pola Bimbingan Orang Tua terhadap Motivasi Belajar Siswa Sekolah Dasar di Era Pandemi Covid-19," J. Temat., vol. 10, no. 3, pp. 129-135, 2020.

[3] C. Sohrabi et al., "World Health Organization declares global emergency: A review of the 2019 novel coronavirus (COVID-19)," Int. J. Surg., vol. 76, no. February, pp. 71-76, 2020.

[4] S. Y. Ariadhy, S. Nurohman, D. Arkum, W. Handini, and F. Ferdiana, "Pelatihan Pembelajaran Jarak Jauh Di Era Pandemi Covid-19," Ariadhy, Shulby Yozar Nurohman, Sabar Arkum, Darol Handini, Widya Ferdiana, vol. 1, no. 3, p. 220, 2020,

[5] R. Pertiwi and S. Sutama, "Membudayakan Kelas Digital Untuk Membimbing Siswa dalam Pembelajaran di Tengah Pandemi Covid-19," JKTP J. Kaji. Teknol. Pendidik., vol. 3, no. 4, pp. 350-365, 2020.

[6] A. G. Prawiyogi, A. Purwanugraha, G. Fakhry, and M. Firmansyah, "Efektifitas Pembelajaran Jarak Jauh Terhadap Pembelajaran Siswa di SDIT Cendekia Purwakarta," J. Pendidik. Dasar, vol. 11, no. 01, pp. 94-101, 2020.

[7] R. Pakpahan and Y. Fitriani, "Analisa Pemafaatan Teknologi Informasi Dalam Pemeblajaran Jarak Jauh Di Tengah Pandemi Virus Corona Covid-19," JISAMAR (Journal Inf. Syst. Applied, Manag. Account. Researh), vol. 4, no. 2, pp. 30-36, 2020.

[8] Zulfikar, "Efektifitas Penggunaan Media Zoom Terhadap Pembelajaran Pada Masa Pandemi Covid-19," J. Ilm. Pranata Edu, vol. 2, no. 1, pp. 33-39, 2020.

[9] A. M. Basar, "Problematika Pembelajaran Jarak Jauh Pada Masa Pandemi Covid-19 (Studi Kasus di SMPIT Nurul Fajri-Cikarang Barat-Bekasi)," Edunesia J. Ilm. Pendidik., vol. 2, no. 1, pp. 208-218, 2021. 